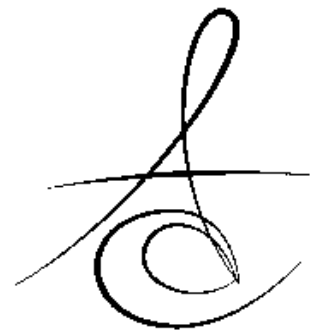

\title{
ORAL HEALTH ATTITUDES AND BEHAVIORS AMONG PATIENTS IN A DENTAL HOSPITAL IN ANKARA, TURKEY
}

\section{ANKARA'DAKİ BİR DİŞ HASTANESİNDE HASTALARIN AĞIZ SAĞLIĞI TUTUM VE DAVRANIŞLARI}

\author{
Dr. Nuran ÖZYEMIş̧Ci CEBECI* $\quad$ Dr. Gökçe SOĞANCI**
}

\begin{abstract}
Makale Kodu/Article code: 1677
Makale Gönderilme tarihi: 07.05.2014

Kabul Tarihi: 01.09.2014
\end{abstract}

\section{ABSTRACT}

Purpose: Information about public's knowledge and attitude about oral diseases and their prevention would indicate the need for education of the community. The objective of this study was to have a foresight about oral health attitude and behavior among adult patients in a state dental hospital, Ankara.

Material and Method: Questionnaire was prepared using Turkish version of Hiroshima University Dental Behavioural Inventory (HU-DBI) and additional 7 questions. 258 number of patients participated. Edentulous patients and patients under 12 years old were kept out of the study. Pearson's ChiSquare, Kruskall-Wallis $\mathrm{H}$ and Mann-Whitney $\mathrm{U}$ Tests were used to analyse the results.

Results: The average age was 33.0. Of the participants, $51.2 \%$ was female and $48.8 \%$ was male. $14.3 \%$ of the patients was graduated from primary school, $12.1 \%$ secondary school, $36.4 \%$ high school, $3.9 \%$ open university, $33.3 \%$ university and post graduate. The mean HU-DBI score was 5.3 (out of 12). Females had significantly higher HU-DBI scores than males $(p=0.039)$. Individuals brushing before sleep had significantly high scores $(p=0.0001)$. Females brushed their teeth before sleep more than males $(p=0.019)$. Females preferred medicine first more than males $(p=0.019)$. Statistically significant difference in prefering medicine first was determined in the group of primary school $(p=0.012)$. As level of education increased, usage rate of dental floss increased $(p=0.018)$.

Conclusions: Oral health attitude and behavior of the population studied was not satisfactory. Oral health education should be provided for the community.

Keywords: Dental hospital, oral health attitude, oral health behavior, questionnaire, Ankara.

\section{ÖZET}

Amaç: Halkın ağız hastalıkları ve korunma yolları hakkında bilgi ve tutumları, toplumun ilgili alanda eğitim intiyacını göstermektedir. Bu çalışmanın amacı, Ankara'daki bir devlet diş hastanesine gelen yetişkin hastaların ağız sağlığı davranış ve tutumları hakkında bilgi edinmektir.

Gereç ve Yöntem: Hiroshima Dental Davranış Envanteri (Hiroshima University Dental Behavioural Inventory, HU-DBI) adı ile anılan standart anketin Türkçe formuna 7 adet soru eklenerek ağız sağlığı tutumu ile ilgili bir anket hazırlandı. Çalışmaya 258 adet hasta katıldı. Tam dişsiz hastalar ve 12 yaş altı bireyler çalışmaya dahil edilmedi. Sonuçlar Pearson KiKare, Kruskall-Wallis $\mathrm{H}$ ve Mann-Whitney $\mathrm{U}$ Testleri ile analiz edildi.

Bulgular: Ankete katılanların yaş ortalaması 33.0 olarak bulundu. Katılanların \%51.2'i kadın, \%48.8'u erkekti. \%14.3'ü ilkokul, \%12.1'si orta okul, \%36.4'ü lise, \%3.9'u açık öğretim, \%33.3'ü yüksek öğretim mezunuydu. HU-DBI skoru 12 üzerinden ortalama 5.3 olarak saptandı. Kadınların HU-DBI skoru, erkeklere göre daha yüksek bulundu ( $p=0.039)$. Yatmadan önce diş fırçalayan hastaların HU-DBI skorları daha yüksekti $(p=0.0001)$. Yatmadan önce diş fırçalamanın, kadınlarda daha fazla olduğu saptandı $(p=0.019)$. Kadınlarda önce ilaç kullanmayı tercih etme erkeklere göre daha yüksek oranda bulundu $(p=0.019)$. Önce ilacı tercih etme, istatiksel olarak belirgin farkla ilkokul grubunda saptandı $(p=0.012)$. Eğitim seviyesi yükseldikçe diş ipi kullanımının arttığı ortaya çıktı $(p=0.018)$.

Sonuç: Çalışma yapılan popülasyonun ağız sağlığı davranış ve tutumları yeterli değildi. Bu sonuca dayanarak, ağız sağlığı konusunda halka eğitim verilmesinin uygun olacağı düşünülmektedir.

Anahtar kelimeler: devlet hastanesi, ağız sağığı davranışı, ağız sağlığı tutumu, anket, Ankara.

\footnotetext{
* Hacettepe University Polatlı Health Services Vocational School, Ankara

${ }^{* *}$ Ministry of Health Topraklık Oral and Dental Health Center, Ankara,
} 


\section{INTRODUCTION}

Oral health and general health status depend on a dynamic interplay of many factors, including the individual's personal characteristics, behaviors and perceptions. ${ }^{1}$ Oral health behavior is influenced by several factors; such as socioeconomic status, knowledge about and attitudes towards oral health. ${ }^{2}$

The Hiroshima University Dental Behavioural Inventory (HU-DBI) questionnaire was developed by Kawamura dealing mainly with oral health attitudes and behavior of patients in tooth brushing. It has first been administered in Japan and demonstrated to be a useful instrument in understanding the perceptions of patients and oral health behavior. Then it has been used for evaluating the differences in oral health behaviors between dental students from different countries due to the curriculum dissimilarities of dental students and variety between the cultures. ${ }^{3,4}$

Previous studies about oral health attitudes and behavior using HU-DBI questionnaire, mostly majored on dental students ${ }^{5-9}$, dental hygiene students ${ }^{9}$, parents ${ }^{10,11}$, diabetic patients ${ }^{12,13}$ There is limited data about oral health attitudes and behavior of adults in general population using HU-DBI questionnaire. There were few researches about oral health knowledge of Turkish population which was different with the questions of the surveys. ${ }^{14}$

\section{METHODS}

The HU-DBI is a 20-item questionnaire in dichotomous response format (agree/disagree) dealing with oral health attitudes and behavior. The original questionnaire was written in Japanese. Turkish translation of the HU-DBI and additional 8 items was used in this study (Table 1, additional items 21 to 28). The translation of the HU-DBI (Turkish version) was used by Doğan et al. ${ }^{15}$, Yildiz and Doğan ${ }^{3}$ in similar studies. Doğan and Yildiz reported that Kappa coefficient of each of 20 items was 1.0. This Turkish version of the HU-DBI was used in this study considering its reliability. The additional items were needed to learn more about oral hygiene practices and habits of the participants. Background information was gathered on age, gender and education.

The study population consisted of 258 patients who visited a state dental hospital in Ankara, Turkey.
Subjects were selected by random from volenteer patients waiting for their appoinment. The majority of the questions were suitable for dentates. Thus, edentulous patients were excluded. Patients under 12 years old were kept out of the study to eliminate mixed dentition factors. Subjects with physical disability were also eliminated considering the effect of disability on providing oral hygiene care.

Table 1. Questionnaire items and answers.

\begin{tabular}{|c|c|c|c|c|c|}
\hline \multicolumn{2}{|r|}{ Item number and descriptions } & \multicolumn{2}{|c|}{ Agree } & \multicolumn{2}{|c|}{ Disagree } \\
\hline & & $\%$ & Number & $\%$ & Number \\
\hline 1. & I don't worry much about visiting dentist. & 51,2 & 132 & 48,8 & 126 \\
\hline 2. & $\begin{array}{l}\text { My gums tend to bleed when I brush my } \\
\text { teeth. }\end{array}$ & 55,8 & 144 & 44,2 & 114 \\
\hline 3. & I worry about the colour of my teeth. & 66,3 & 171 & 33,7 & 87 \\
\hline 4. & $\begin{array}{l}\text { I have noticed some white sticky deposits } \\
\text { on my teeth. }\end{array}$ & 40,3 & 104 & 59,7 & 154 \\
\hline 5. & I used a child-sized toothbrush. & 5,8 & 15 & 94,2 & 243 \\
\hline 6. & $\begin{array}{l}\text { I think that I cannot help having false } \\
\text { teeth when I am old } \\
\end{array}$ & 46,8 & 121 & 53,2 & 137 \\
\hline 7. & I am bothered by the colour of my gums. & 47,3 & 122 & 52,7 & 136 \\
\hline 8. & $\begin{array}{l}\text { I think my teeth are getting worse despite } \\
\text { my daily brush. }\end{array}$ & 53,1 & 137 & 46,9 & 121 \\
\hline 9. & I brush each of my teeth carefully. & 64,7 & 167 & 35,3 & 91 \\
\hline 10. & $\begin{array}{l}\text { I have never been taught professionally } \\
\text { how to brush. }\end{array}$ & 29,4 & 76 & 70.6 & 182 \\
\hline 11. & $\begin{array}{l}\text { I think I can clean my teeth well without } \\
\text { using toothpaste. }\end{array}$ & 20,1 & 52 & 79,9 & 206 \\
\hline 12. & $\begin{array}{l}\text { I often check my teeth in a mirror after } \\
\text { brushing alone. }\end{array}$ & 75,1 & 194 & 24,9 & 64 \\
\hline 13. & I worry about having bad breath. & 94,1 & 243 & 5,9 & 15 \\
\hline 14. & $\begin{array}{l}\text { It is impossible to prevent gum disease } \\
\text { with tooth brushing alone. }\end{array}$ & 40,3 & 104 & 59,7 & 154 \\
\hline 15. & $\begin{array}{l}\text { I put off going to the dentist until I have a } \\
\text { toothache. }\end{array}$ & 76,3 & 197 & 23,7 & 61 \\
\hline 16. & $\begin{array}{l}\text { I have used a dye to see how clean my } \\
\text { teeth are. }\end{array}$ & 4,2 & 11 & 95,8 & 247 \\
\hline 17. & $\begin{array}{l}\text { I used a toothbrush which has a hard } \\
\text { bristles. }\end{array}$ & 24,3 & 63 & 75,7 & 195 \\
\hline 18. & $\begin{array}{l}\text { I do not feel I've brushed well unless I } \\
\text { brush strong strokes. }\end{array}$ & 18,6 & 48 & 81,4 & 210 \\
\hline 19. & $\begin{array}{l}\text { I feel I sometimes take too much time to } \\
\text { brush my teeth. }\end{array}$ & 25,1 & 65 & 74,9 & 193 \\
\hline 20. & $\begin{array}{l}\text { I have had my dentist tell me that I brush } \\
\text { very well. }\end{array}$ & 16,6 & 43 & 83,4 & 215 \\
\hline 21. & I smoke. & 36,4 & 94 & 63,6 & 164 \\
\hline 22. & $\begin{array}{l}\text { I always brush my teeth before sleep at } \\
\text { night. }\end{array}$ & 61,6 & 159 & 38,4 & 99 \\
\hline 23. & $\begin{array}{l}\text { When I have a toothache, I prefer taking } \\
\text { medicine to visiting dentist first. }\end{array}$ & 40,7 & 105 & 59,3 & 153 \\
\hline 24. & $\begin{array}{l}\text { After I take a medicine, I put off visiting } \\
\text { dentist until my toothache returns. }\end{array}$ & 44,2 & 114 & 55,8 & 144 \\
\hline 25. & I drink tea or coffee a lot in a day. & 62,2 & 160 & 38 & 98 \\
\hline 26. & $\begin{array}{l}\begin{array}{l}\text { I think I should visit a dentist once every } \\
\text { six months. }\end{array} \\
\end{array}$ & 71,7 & 185 & 28,3 & 73 \\
\hline 27. & I use oral rinse. & 20,2 & 52 & 79,8 & 206 \\
\hline 28. & I use dental floss. & 16,7 & 43 & 83,3 & 215 \\
\hline
\end{tabular}


The score of each item in the HU-DBI was based on analytical research in which a statistical model was developed. One point was given for each of agree responses to the items 4, 9, 11, 12, 16, 19 and one point was given for each of disagree response to the items $2,6,8,10,14,15$. Maximum possible score was 12. Higher scores signified better oral health attitude and behavior.

The SPSS version 20.0 (IBM Corp, NY) was used for performing statistical analyses througout the study. Correlation between demographic data (age, gender, education) and answers to additional questions 21 to 28 was analyzed by Pearson's ChiSquare Test. Correlation between age, gender, education and HU-DBI scores was analyzed by Kruskall-Wallis $\mathrm{H}$ Test. Correlation between questions 21 to 28 and HU-DBI scores was analyzed by MannWhitney U Test.

\section{RESULTS}

The average age of the participants was 33.0. Of 258 patients responded, 132 was female and 126 was male. $14.3 \%$ of the patients was graduated from primary school, $12 \%$ secondary school, $36.4 \%$ high school, 3.9\% open university, 33.3\% university and post graduate. Distribution of the subjects by age, gender and education is shown in Graphic 1, Graphic 2 and Graphic 3 respectively.

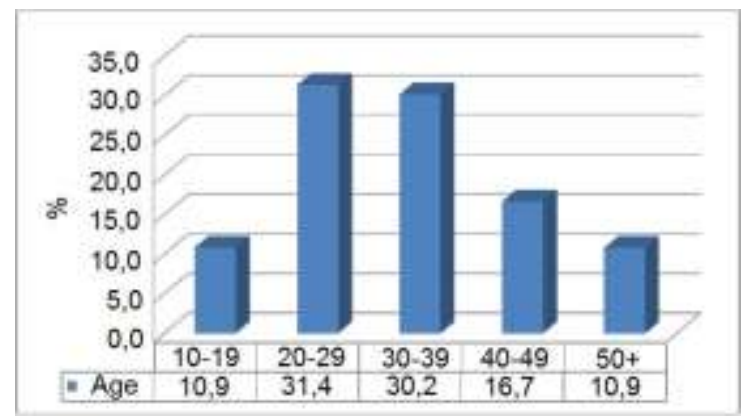

Graphic 1. Distribution of the subjects by age.

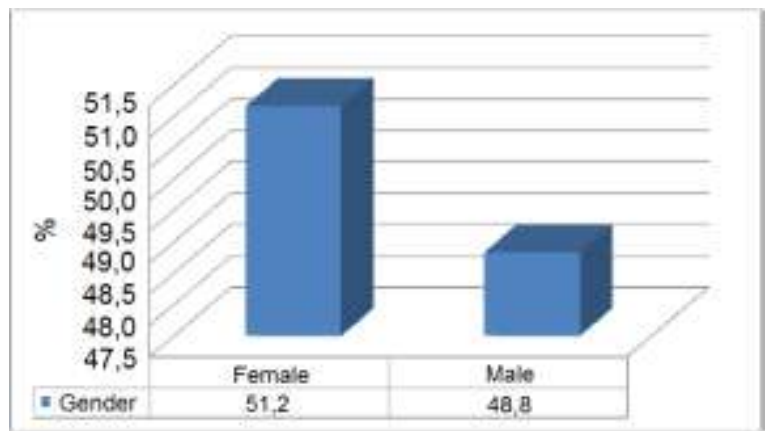

Graphic 2. Distribution of the subjects by gender.

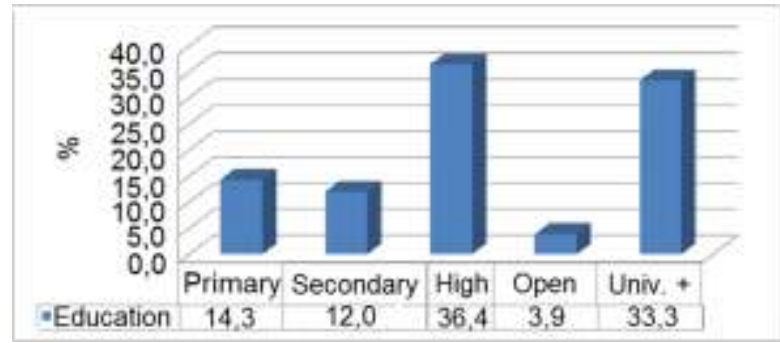

Graphic 3. Distribution of the subjects by education.

Correlation between demographic data and answers to additional questions:

There were significant difference between gender and answers of 4 additional questions. Females preferred medicine to visiting dentist more than males $(p=0.019)$. Females put off visiting dentist until they had a toothache more than males $(p=0.007)$. Statistically significant difference in prefering medicine to visiting dentist was determined in the group of primary school $(p=0.012)$. As level of education increased, usage rate of dental floss increased $(p=0.018)$.

Correlation between demographic data and HU-DBI scores:

There was no significant difference between age, education and HU-DBI scores $(p>0.05)$. There was significant difference between gender and HU-DBI scores $(p<0.05)$. Females had significantly higher scores than males $(p=0.039)$.

Correlation between additional questions and HU-DBI scores:

Individuals brushing before sleep had significantly high HU-DBI scores $(p=0.0001)$. Not to drink coffee and/or tea a lot was resulted in significantly high scores $(p=0.043)$. Also individuals

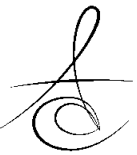


using dental floss had definitely high scores $(p=0.046)$. There was no significantly difference between rest of additional questions (smoking, taking medicine before visiting dentist, puting off visiting dentist after taking medicine, visiting dentist once every 6 months, using oral rinse) and HU-DBI scores ( $p>0.05)$.

\section{DISCUSSION}

This study involved a sample of Turkish dental patients who attended a state dental hospital. Studies about oral health attitudes and behavior in Turkey is limited with dental students $3,7,15$ and elder population. ${ }^{16}$ This study searched oral health attitudes and behavior of adults in a Turkish population.

This study showed that females gave priority to medicine over clinical examination in the presence of toothache. This finding is consistent with the result of a survey about prevalence of analgesic use in a Turkish population. Ozkan et al. ${ }^{17}$ reported that nonprescription analgesics were more prevalent among females. This may be due to dental fear and anxiety. Previous studies about dental anxiety and fear in Turkish population showed that dental anxiety level of women was higher than men. ${ }^{18-20}$ Armfield $^{21}$ concluded that dental fear acted as a determinant of avoiding or delaying dental visit.

As the level of education increased, tendency to take medicine instead of clinical examination decreased. It was probably because the higher education may cause awareness of rational medication. According to Ozkan's survey in Turkish population university graduates had the lowest prevalence of non-prescription analgesics. ${ }^{17}$ Also it may be result of dental fear and anxiety in undereducated patients. Erten et al. ${ }^{19}$ reported Turkish patients with a primary education had the highest anxiety scores. Firat emphasized the negative correlation between dental fear scale and education level of a Turkish population. ${ }^{20}$

The majority of participants did not use dental floss $(83.3 \%)$. This finding was similar to a study from Japan $(81.3 \%)^{22}$ and Jordan $(89.6 \%)^{23}$. However, the rate of not flossing was higher than reported in other studies from Canada $(28.1 \%)^{24}$, Sweden $(54.5 \%)^{2}$, Romania $(58.6 \%)^{25}$. The use of dental floss increased as the education status increased as was reported by
Kakoei et al. ${ }^{26}$ and Tseveenjav et $\mathrm{al}^{27}$. But there was no correlation between use of oral rinse and education in this study. Only the minority of respondents used mouthwash $(20.2 \%)$. The rate of rinsing was lower than reported in other surveys from Sweden $(38.1 \%)^{2}$ and Romania $(56.2 \%)^{25}$.

In our study, the mean HU-DBI score was 5.3 (out of 12). This score was similar to the result of Levin and Shenkman's ${ }^{1}$ survey among young Israeli adults (5.8) and higher than Kawamura et al.'s ${ }^{4}$ survey among Japanese adults (4.4). Females had significantly higher HU-DBI scores than males $(p=0.039)$. This finding is consistent with the result reported by Kawamura et $\mathrm{al}^{4}$. In contrast to our result, Levin showed no relation between gender and HU-DBI scores.

A relation between education level and HU-DBI scores was supposed to be. But there was no significant difference between age, education and HUDBI scores. Individuals who brush their teeth before sleep, not drink coffee and/or tea a lot and use dental floss had definitely high scores.

Shekar et al. ${ }^{28}$ emphasized the direct relation between the favorable dental health awareness, attitude, oral hygiene behavior and socioeceonomic status. Although socioeceonomic factor was not included in the study, state dental hospitals in Turkey were prefered by patients with low socioeconomic status. $^{29-32}$ Only $33.3 \%$ of the participants was graduated from university and post graduate. This may explain low rate of using dye $(4.20 \%)$, oral rinse (20.10\%) and floss (16.60\%). However, $61.60 \%$ of the participants brushed their teeth before sleep time and $71.70 \%$ of the participants thought they should visit a dentist once every six months.

Dentists are mainly concerned with the treatment of oral diseases rather than prevention of diseases and promotion of oral health. Information about public's knowledge and attitude about oral diseases and their prevention indicates the need for education of the community. This study aimed to get information about oral health attitudes and behavior of a group of Turkish community. The survey was carried out in capital of Turkey and the findings can not be generalized to the entire country. It would be more useful to make a survey in different regions of the country. Although it involves a limited population, this study provides data about oral health attitude and 
behavior among adults visiting state hospital in Turkey. Also, a questionnaire would rather be supported with clinical examination. Results indicates that health professionals should study popular and folk sectors of health care because most of the health care occurs within these sectors.

\section{CONCLUSION}

Oral health attitudes and behavior of the patients studied was poor. Education of the community about oral health care and awareness should be improved.

\section{ACKNOWLEDGEMENTS}

The authors express their appreciation to Ministry of Health Ankara Topraklık Oral and Dental Health Center and survey participants for their support throughout the study.

\section{REFERENCES}

1. Levin L, Shenkman A. The Relationship Between Dental Caries Status and Oral Health Attitudes and Behavior in Young Israeli Adults. J Dent Educ 2004; 68: 1185-91.

2. Jensen O, Gabre P, Sköld UM, Birkhed D. Is the use of fluoride toothpaste optimal? Knowledge, attitudes and behaviour concerning fluoride toothpaste and toothbrushing in different age groups in Sweden. Community Dent oral Epidemiol 2012; 40: 175-84.

3. Yildiz S, Dogan B. Self Reported Dental Health Attitudes and Behaviour of Dental Students in Turkey. Eur J Dent 2011; 5: 253-9.

4. Kawamura M, Sasahara H, Kawabata K, Iwamoto $Y$, Khonishi K, Wright FAC. Relationship between CPITN and oral health behaviour in Japanese adults. Aust Dent J 1993; 38: 381-8.

5. Komabayashi T, Kwan SYL, Hu DY, Kajiwara K, Sasahara $\mathrm{H}$, Kawamura M. A comparative study of oral health attitudes and behaviour using the Hiroshima University - Dental Behavioural Inventory (HU-DBI) between dental students in Britain and China. J Oral Sci 2005; 47: 1-7.
6. Kawamura M, Honkala $E$, Wisdtröm $E$, Komabayashi T. Cross-cultural differences of selfreported oral health behaviour in Japanese and Finnish dental students. Int Dent J 2000; 50: 4650.

7. Doğan B. Differences in Oral Health Behavior and Attitudes Between Dental and Nursing Students. MÜSBED 2013; 3: 34-40.

8. Rahman B, Kawas SA. The relation between dental health behavior, oral hygiene and gingival status of dental students in the United Arab Emirates. Eur J Dent 2013; 7: 22-7.

9. Wahadni AM, Omiri MK, Kawamura M. Differences in self-reported oral health behavior between dental students and dental technology/dental hygiene students in Jordan. J oral Sci 2004; 46: 191-7.

10. Okada M, Kawamura M, Kaihara Y, Matsuzaki Y, Kuwahara $S$, Ishidori $H$. Influence of parents' oral health behaviour on oral health status of their school children: an exploratory study employing a causal modelling technique. Int J Paediatr Dent 2002; 12: 101-8.

11. Okada M, Kawamura M, Hayashi Y, Takase N, Kozai K. Simultaneous interrelationship between the oral health behavior and oral health status of mothers and their children. J Oral Sci 2008; 50: 447-52.

12. Kawamura M, Fukuda S, Kawabata K, Iwamoto Y. Comparison of health behaviour and oral/medical conditions in non-insulin-dependent (type II) diabetics and non-diabetics. Aust Dent J 1998; 43: 315-20.

13. Kawamura M, Tsurumoto A, Fukuda S, Sasahara H. Health behaviors and their relation to metabolic control and periodontal status in type 2 diabetic patients: a model tested using a linear structural relations program. J Periodontol 2001; 72: 124653.

14. Kara MC, Zihni M. Knowledge level of patients in Erzurum region about oral and periodontal health. Atatürk Üniv. Diş Hek Fak Derg 2004; 14: 1-8.

15. Doğan B, Filizi K, Küçükdoğan Ü. Gender-specific oral health attitudes and behavior among dental students. GÜ Diş Hek Fak Derg 2009; 26: 87-93.

16. Ünlüer Ş, Gökalp S, Doğan BG. Oral health status of elderly in a residential home in Turkey. Gerodontology 2007; 24: 22-9.

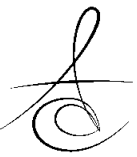


17. Ozkan O, Hamzaoglu O, Erdine S, Balta E, Domac M. Use of analgesics in adults with pain complaints: prevalence and associated factors, Turkey. Rev Saude Publica 2009; 43: 140-146.

18. Pekkan G, Kilicoglu A, Hatipoglu H. Relationship between dental anxiety, general anxiety level and depression in patients attending a university hospital dental clinic in turkey. Community Dent Health 2011; 28: 149-53.

19. Erten HA, Zühre ZB, Emre. Dental fear and anxiety levels of patients attending a dental clinic. Quintessence Int 2006; 37: 304-10.

20. Firat D, Tunc EP, Sar V. Dental anxiety among adults in Turkey. J Contemp Dent Pract 2006; 7: 75-82.

21. Armfield JM. What goes around comes around: revisiting the hypothesized vicious cycle of dental fear and avoidance. Community Dent Oral Epidemiol. 2013; 41: 279-87.

22. Kawamura M, Iwamoto Y. Present state of dental health knowledge, attitudes/behavior and perceived oral health of Japanese employees. Int Dent J 1999; 49: 173-81.

23. Khader YS. Factors associated with periodontal diseases in Jordan: principal component and factor analysis approach. J Oral Sci 2006; 48: 77-84.

24. Ramraj C, Azarpazhooh A, Dempster L, Ravaghi V, Quiñonez C. Dental treatment needs in the Canadian population: analysis of a nationwide cross-sectional survey. BMC Orak Health 2012; 12: 46-55.

25. Dumitrescu AL, Wagle M, Dogaru BC, Manolescu B. Modeling the theory of planned behavior for intention to improve oral health behaviors: the impact of attitudes, knowledge, and current behavior. J Oral Sci 2011; 53: 369-77.

26. Kakoei S, Parirokh M, Nakhaee N, Jamshidshirazi F, Rad M, Kakooei S. Prevalence of toothache and associated factors: a population-based study in southeast Iran. Iran Endod J 2013; 8: 123-8.

27. Tseveenjav B, Suominen-Taipale L, Varsio S, Hausen $H$, Knuuttila M, Vehkalahti MM. Patterns of oral cleaning habits and use of fluoride among dentate adults in Finland. Oral Health Prev Dent 2010; 8: 287-94.
28. Shekar BRC, Reddy CVK, Manjunath BC, Suma S. Dental health awareness, attitude, oral healthrelated habits, and behaviors in relation to socioeconomic factors among the municipal employees of Mysore city. Ann Trop Med Public Health 2011; 4: 99-106.

29. Akça S, Akan B, Baysal Z. Patient satisfaction in Oral and Dental Health Centers "Bolu İzzet Baysal Oral and Dental Health Center". Ankara: Turkish Republic Ministry of Health Organisation 2013, publication no. 900.

30. Yurtsever S, Çakmak AÇ. Measurement of service qulity in hospitals using patient satisfaction state: a survey about inpatients in Karabük State Hospital. Ankara: Turkish Republic Ministry of Health Organisation 2013, publication no. 899.

31. Kanber NA, Gürlek Ö. The effect of the number of beds in a patient room on the patient pleasure. Ankara: Turkish Republic Ministry of Health Organisation 2013, publication no. 899.

32. İncesu $E$, Yüzüak $Z$, Tombul C. Accessibility of health service at home: accessibility of service by patients in Homehealth Unit of Konya Seydişehir State Hospital. Ankara: Turkish Republic Ministry of Health Organisation 2013, publication no. 899.

\section{Yazışma Adresi:}

Nuran Özyemişci-Cebeci

Hacettepe University

Polatı Health Services Vocational School.

Şehitlik Mahallesi Şehitlik Karşı Mevkii.

Prof. Dr. Kemal Bıyıklığlu Street No: 18

PK.06900 Polatlı Campus. Polatlı/ Ankara

Phone: (+90) (312) 6211024

Fax: (+90) (312) 6238850

E-mail: nozyemisci@yahoo.com 